\title{
The Impact of Myriad and Mayo: Will Advancements in the Biological Sciences Be Spurred or Disincentivized? (Or Was Biotech Patenting Not Complicated Enough?)
}

\author{
Jennifer Gordon \\ Paul, Weiss, Rifkind, Wharton \& Garrison, LLP, New York, New York 10019-6064 \\ Correspondence: jengordon@paulweiss.com
}

\begin{abstract}
For years, purified and isolated naturally occurring biological substances of great medical importance-including genes—have been the subject of U.S. patents. Similarly, methods in which the detection of a biological substance (e.g., in a blood sample) dictates subsequent actions, as in disease diagnostics and treatment, have long enjoyed patent protection. However, two recent Supreme Court cases, Association for Molecular Pathology v. Myriad Genetics, Inc. (133 S. Ct. 2107) (2013) and Mayo Collaborative Services v. Prometheus Laboratories, Inc. (132 S. Ct. 1289) (2012), have shaken up the status quo of biotech patenting. The highest court in our land unanimously agreed with patent challengers that much of what we took for granted as patentable subject matter is not, as a matter of law, eligible for patenting after all. This review discusses the Myriad and Mayo cases, their impact on which biologybased innovations we may or may not continue to patent, and whether the altered status quo is benignly corrective or gravely disruptive. Is what happened here a good thing or not?
\end{abstract}

\section{BACKGROUND ON PATENTS AND PATENTABLE SUBJECT MATTER}

M any people are surprised to learn that a patent does not grant the right to practice your invention. Rather, a patent provides exclusive rights-the right to prevent others from making, using, or selling your invention for a limited period of time. ${ }^{1}$ This does not mean

${ }^{1}$ Currently a granted patent expires 20 years after its priority filing date. The protected invention is set forth in numbered "claims" at the end of the patent document, following the full description of the invention in the patent "specification." you may not practice your invention; you may, as long as you are not infringing someone else's patent. The time-limited ability to practice your invention while excluding others from doing so provides a tremendous commercial advantage to a patent holder. Consequently, the promise of a patent's time period of market exclusivity provides an incentive to innovate. The only quid pro quo for this exclusive right is full disclosure of the new, useful, and nonobvious invention, and how to practice it, in the patent document. With full disclosure, the public at large benefits from the technological advancement.

Editors: Salim Mamajiwalla and Rochelle Seide

Additional Perspectives on Intellectual Property in Molecular Medicine available at www.perspectivesinmedicine.org

Copyright (C) 2015 Cold Spring Harbor Laboratory Press; all rights reserved; doi: 10.1101/cshperspect.a020917

Cite this article as Cold Spring Harb Perspect Med 2015;5:a020917 
J. Gordon

Our patent system, and its reward of exclusive rights for invention, originates in the United States Constitution, Article 1, Section 8, which provides, in part, that the Congress shall have the power "to promote the progress of science and useful arts by securing for limited times to authors and inventors the exclusive rights to their respective writings and discoveries [...]."2

But one person's incentivizing exclusive right is another's suspect monopoly with the power to hinder, or at least postpone, progress. As Justice Thomas wrote in Association for Molecular Pathology v. Myriad Genetics, Inc. (133 S. Ct. 2107) (2013):

As we have recognized before, patent protection strikes a delicate balance between creating 'incentives that lead to creation, invention, and discovery' and 'imped[ing] the flow of information that might permit, indeed spur, invention.'3

Our patent law is statutory (Title 35 of the United States Code), but judicial case law has developed to ensure that the "delicate balance" between incentives and hindrances does not become tipped too far in either direction. As will be discussed below, the Supreme Court both in Myriad and in Mayo Collaborative Services $v$. Prometheus Laboratories, Inc. (132 S. Ct. 1289) (2012) viewed certain long-employed conventions for claiming biotech inventions in U.S. patents as having upset this balance, impeding progress by monopolizing subject matter never eligible for patenting in the first place.

The four categories of subject matter eligible for patenting are articulated in 35 U.S.C. \$101:

Whoever invents or discovers any new and useful process, machine, manufacture, or composition of matter. . .may obtain a patent therefor, subject to the conditions and requirements of this title.

The statute does not define these categories to any useful degree. Congress intended them to be broad, allowing many inventions and discoveries to meet $\$ 101$ 's requirements. In effect, $\$ 101$ is

\footnotetext{
${ }^{2}$ (Emphasis added.) Note that the term in the Constitution is "discoveries"- broad enough to encompass not only an invention assembled by man, but also the discovery of something preexisting - like a previously unknown natural product.

${ }^{3} 132$ S. Ct. at 2116 (quoting Mayo, 132 S. Ct. at 1305).
}

an entry gate. What passes through it is to be further tested by the other "conditions and requirements of this title," like $\$ 102$ (requiring that the invention be novel), $\$ 103$ (requiring that it be nonobvious), and $\$ 112$ (setting forth certain disclosure requirements for the patent document itself). These sections serve as finer filters and, in the majority of instances, adequately prevent invalid patent claims from issuing on subject matter that fell within the $\$ 101$ categories. 4

In historically rare instances, however, our Supreme Court has had to address whether the subject matter of claims of issued patents was eligible for patenting. Although the categories of "machine," "manufacture," "composition of matter," and "process" are broad, they are not without limits. The Court has recognized implicit exceptions to the categories of patent-eligible subject matter, including "laws of nature, natural phenomena, and abstract ideas" (Diamond $v$. Diehr (450 U.S. 175, 185) (1981)). Nevertheless, "an application of a law of nature or mathematical formula to a known structure or process may well be deserving of patent protection." 5

The rationale for precluding patent protection on these exceptions is that they are the basic tools of scientific and technological work and should not be monopolizable, for fear of stifling innovation rather than promoting it. In the famous case of Diamond v. Chakrabarty, in which the Supreme Court approved the patentability of a living bacterium engineered to degrade oil,

\footnotetext{
${ }^{4}$ To the thinking of many patent lawyers, whatever the perceived overreach of the claims at issue in Myriad and Mayo, it could adequately have been checked by $\$ \$ 102,103$, and/or 112. However, neither case progressed to the point that these sections of the statute could come into play to invalidate the claims (if warranted). Rather, in both cases, patent claims were challenged, on summary judgment, under $\$ 101$. In neither case was the issue of subject matter eligibility tried on the merits, but rather was presented to the courts as purely an issue of law, devoid of factual disputes. Thus, to many, the procedural histories of these cases are wholly unsatisfying. Query whether a club was used to bludgeon claims that would otherwise have succumbed to a surgical strike by $\$ \$$ 102,103 , and/or 112? Has precedent been set on "bad facts" that will preclude important future innovations from being patented because they will be stopped at the $\$ 101$ gate?

${ }^{5}$ Diamond v. Diehr (450 U.S. 187) (1981).
} 
the court expressed its view about what may not be patented:

[A] new mineral discovered in the earth or a new plant found in the wild is not patentable subject matter. Likewise, Einstein could not patent his celebrated law that $\mathrm{E}=\mathrm{mc}^{2}$, nor could Newton have patented the law of gravity. Such discoveries are "manifestations of. . .nature, free to all men and reserved exclusively to none."

With the Chakrabarty decision, unpatentable "manifestations of nature" expanded to include not only "laws of nature" and "natural phenomena" but also, arguably, products of nature, like minerals and plants in the wild. However, if the product sought to be patented, despite its origins in nature, was "markedly different" than what existed in nature (as was the case with Chakrabarty's engineered bacterium), then such subject matter would be eligible for patenting as a new and useful composition of matter in accordance with 35 U.S.C. $\$ 101$. The Chakrabarty decision ushered in an era of creativity not only in the biotechnological arts but also in the art of biotech patenting.

\section{BIOLOGICAL ADVANCEMENTS: MAN'S PATENTABLE BREAKTHROUGHS OR NATURE'S UNPATENTABLE SECRETS REVEALED?}

Not surprisingly, advancements in biology involve "manifestations of nature." Claiming such advancements as patentable inventions has long been fraught with the danger of violating the prohibition of patenting natural phenomena and natural products. However, courts have also recognized that the natural product and natural phenomena exceptions may be abused:

It only confuses the issue, however, to introduce such terms as "the work of nature" and the "laws

${ }^{6} 447$ U.S. 303, 309 (1980) (quoting Funk Brothers Seed Co. v. Kalo Inoculant Co. (333 U.S. 127, 130) (1948)). Other Supreme Court cases on the patent eligibility of biological inventions are American Fruit Growers, Inc. v. Brogdex Co. (283 U.S. 1) (1931) (oranges with borax-impregnated rinds, making them less susceptible to rot, held not eligible for patenting) and J.E.M. Ag Supply, Inc. v. Pioneer Hi-Bred International, Inc. (534 U.S. 124) (2001) (genetically engineered plants and seeds held eligible for patenting). of nature." For these are vague and malleable terms infected with too much ambiguity and equivocation.... Arguments drawn from such terms for ascertaining patentability could fairly be employed to challenge almost every patent. ${ }^{7}$

Amid these legal tensions, a body of patent-eligible biological subject matter evolved.

\section{Biological Compositions of Matter}

Long before the 1980s, when genes encoding therapeutically important proteins began to be patented, all sorts of natural products were the subjects of claims of U.S. patents, including therapeutically important proteins, antibiotics, vitamins, enzymes used in industrial processes, other natural substances, and even microbial cultures.

The key to distinguishing the product being claimed over the product as it existed in nature was to use claim language that signified a level of purity or degree of isolation for the product that would not exist in nature. Words like "isolated," "purified," and "homogeneous" became the terminology of biological patent claims covering otherwise natural products. Such terms ensured that a prohibited subject matter category was not being claimed. Rather, something "markedly different" than what existed in nature was being claimed.

The rationale for allowing patent claims to purified or isolated substances was articulated in 1911 by Judge Learned Hand in the case of Parke-Davis \& Co. v. H.K. Mulford Co., involving purified adrenaline. Judge Hand reasoned that the new utility of the product conferred patent eligibility:

[E]ven if it were merely an extracted product without change, there is no rule that such products are not patentable. [The inventor] was the first to make it available for any use by removing it from the other gland-tissue in which it was found, and, while it is of course possible logically to call this a purification of the principle, it became for every practical purpose a new thing

${ }^{7}$ Funk Brothers Seed Co. (333 U.S. at 134-35) (Frankfurter, J., concurring) (emphasis added). 
commercially and therapeutically. That was a good ground for a patent. ${ }^{8}$

Similar thinking prevailed in Merck \& Co. v. Olin Mathieson Chemical Corp., in which, in upholding patent claims to vitamin $\mathrm{B}_{12}$ compositions, the court stated:

The compositions of the patent here have all of the novelty and utility required by the Act for patentability. They never existed before; there was nothing comparable to them. If we regard them a purification of the active principle in natural fermentates, the natural fermentates are quite useless, while the patented compositions are of great medicinal and commercial value. The step from complete uselessness to great and perfected utility is a long one. That step is no mere advance in the degree of purity of a known product. From the natural fermentates, which, for this purpose, were wholly useless and were not known to contain the desired activity in even the slightest degree, products of great therapeutic and commercial worth have been developed. The new products are not the same as the old, but new and useful compositions entitled to the protection of the patent. ${ }^{9}$

In re Merz perhaps most succinctly states the concept that patent eligibility of a purified or isolated natural product flows from its serving purposes that the natural product cannot: "[I]f the process produces an article of such purity that it differs not only in degree but in kind, it may be patentable. If it differs in kind, it may have a new utility in which invention may rest."

None of these cases made it to the Supreme Court, and the practice of claiming natural products to some specified (usually high) level of purity became firmly entrenched in patent practice. In many instances, the processes used to purify the natural product were new and nonobvious, and thus patentable, in their own right. The word "purified" or "isolated" in the product claim, perhaps, took on the aura of the inventive contribution that went into uncovering and/or identifying an unknown biological molecule and providing it in a useful form not previously possible. When the purified substance was a

${ }^{8} 189$ F. 95, 103 (S.D.N.Y. 1911) (emphasis added).

${ }^{9} 253$ F.2d 156, 164 (4th Cir. 1958) (emphasis added).

${ }^{10} 97$ F.2d 599, 601 (C.C.P.A. 1935) (emphasis added). medical breakthrough of great significance, like adrenaline or vitamin $B_{12}$, that only added to its aura of patent eligibility.

There may have been other thinking at play in these cases: The implicit understanding that providing patent protection for what likely was a specific purification process was not a sufficient reward. The prize was the purified natural substance itself, which, once known, could be derived by other purification methods outside the scope of any patent claim to the first purification process to uncover the substance. The more appropriate reward was to grant patent protection to the purified or isolated natural substance itself, as a composition of matter. That was the way to incentivize valuable discoveries of never previously known natural products.

As we entered the era of cloning, another biological substance, DNA, became the subject of patent claims. Recombinant DNA technologies focused on isolating genes that encoded useful proteins from their native hosts and transferring the genes to unicellular organisms. For example, human cells were the source of genes encoding therapeutically important proteins like human growth hormone, insulin, erythropoietin, and interferons. The recombinant organisms engineered to contain copies of the human gene could then serve as living factories producing valuable proteins in quantities not practically achievable from native sources, and at much lower cost.

Typically, the experimental approach was to use the amino acid sequence of a known, desired protein to design hybridization probes that could fish out mRNA from native cells that made the protein. Then the mRNA would be reverse transcribed to make complementary DNA (cDNA), which could be sequenced. The cDNA was also cloned into replicable vectors which, in turn, were transfected into host cells to make recombinant organisms that produced the proteins. Recombinant DNA technologies offered a plethora of new compositions of matter for which patent protection was sought and awarded.

To those who were first to obtain the native DNA sequences encoding useful proteins, U.S. patents claiming such DNA molecules were 
awarded. Conventions evolved for claiming these molecules. Although the term "purified" was sometimes used in patent claims to DNA, more often the word chosen was "isolated." In fact, up until the Myriad case, the term "isolated" was approved by the U.S. Patent and Trademark Office (USPTO) as the word that would signify that the DNA molecule being claimed was distinct from what existed in nature. "Isolated" conveyed that the DNA molecule was no longer in its natural milieu and/or no longer part of a greater chromosome. It was a new molecule, and the native DNA sequence, never before known, was nonobvious. Prior to Myriad, no one focused on whether the act of isolating the DNA was inventive enough to lend patentability to a DNA molecule, the nucleotide sequence of which was never before known. This is because the isolated DNA, even if its sequence were no different than that of the DNA as it existed in nature, was viewed as the invention, not the process for isolating it. It was a discovery worthy of patent protection. As long as it was claimed in a way that did not read on nature, the USPTO did not question its patent eligibility. The word "isolated" in the claim thus allowed the DNA to pass through the $\$ 101$ gateway. ${ }^{11}$

In the case of cDNA molecules comprising exons only, and not the introns found in genomic DNA, there was no question that such molecules are man-made and not a product of nature. The Supreme Court in Myriad agreed and affirmed the patent eligibility of cDNA molecules. But as biotechnology developed, the practice of claiming isolated DNA molecules did not stop with claiming isolated cDNAs. Another convention of DNA patent claiming was to claim an isolated DNA encoding a polypeptide of a specified amino acid sequence. Claiming DNA in terms of the encoded protein provided broader coverage to a genus of DNAs. That genus included not only a cDNA molecule with the native nucleotide sequence, but also synthetic DNA molecules that had varied nucleotide sequences based on the degeneracy of the

${ }^{11}$ The word "isolated" in patent claims to human genes also ensured that the claim would not be infringed by humans who carried the gene within the chromosomes of their cells. genetic code, which nevertheless encoded the same protein. Last, a claim to "an isolated DNA encoding a peptide [of the following specific amino acid sequence]" also encompassed an isolated version of the native genomic DNA (e.g., in the case of eukaryotes, DNA comprising the nucleotide sequences of exons and introns, as would exist in nature). After decades of claiming DNA in this fashion, we learned in Myriad that such claims run afoul of Supreme Court precedent prohibiting the patenting of products of nature and natural phenomena.

\section{Natural Correlations}

Many biological substances, whatever their natural functions may be, can serve an informational purpose. For example, high levels of cholesterol in blood may signify coronary disease. Substances that correlate with disease, or the potential of developing disease, are of great diagnostic significance. They are often referred to as "biomarkers," flags, if you will, that indicate a need to monitor or commence a course of prevention or treatment. When one considers the importance of early detection to the management and care of, for example, cancers or heart disease, or the benefit to patients of being able to diagnose disease based on a simple blood, or better yet, urine or saliva, sample instead of an invasive tissue biopsy, it is not difficult to understand why medical researchers seek easily detectable and/or measurable biomarkers that correlate with disease. In this modern age of genomics, disease-correlating biomarkers frequently are segments of DNA, more specifically, mutant sequences that signify a problem. Biomarker DNA is not generally sought for its ability to encode protein, as is the case with recombinant DNA technology, where the reward is in the complete gene that encodes a useful protein. Rather, the focus is on identifying the nucleotide sequence(s) that will provide diagnostic information. The search for useful genetic biomarkers is often no small feat. Discovering biomarkers, as well as devising diagnostic methods based on them, had been uncontroversially rewardable with U.S. patents until Myriad and Mayo changed the playing field. 
J. Gordon

Although it was understood that a simple claim to something like "the correlation of biomarker A with disease B" or "the use of biomarker A to diagnose disease B" impermissibly claimed a natural phenomenon, patent claims were nevertheless pursued to the biomarkers as isolated or purified compositions of matter. Furthermore, it was also common patent practice to claim diagnostic methods in a format that sets forth steps such as:

[a] method for diagnosing a predisposition for disease $\mathrm{X}$ in a human subject which comprises obtaining a sample from a patient, and determining [or detecting] the presence of biomarker $\mathrm{Y}$, wherein the presence of biomarker $\mathrm{Y}$ in the sample indicates a predisposition for disease X.

Hundreds, if not thousands, of such claims have been issued over the years by the USPTO without questioning whether the method, so worded, falls into the patent-eligible category of “process" set forth in 35 U.S.C. \$101. It was accepted that it did.

In addition to their importance in disease diagnostics, biomarkers are being hotly pursued in the growing field of personalized medicine. Their detection in a patient provides information that is used to make therapeutic treatment decisions, matching that particular patient with an appropriate drug and/or appropriate dose. Usually, the biomarker is a genetic sequence, and the pharmacogenetic test for it identifies whether the patient is a responder or nonresponder to a particular drug and/or whether the patient is likely to suffer adverse effects that would contraindicate the use of the drug. This type of testing is also referred to as "companion diagnostics," in which a drug is not administered to a patient unless or until the diagnostic has been performed and it is appropriate to do so. There are obvious benefits to matching patients to drugs that will be most efficacious for them while minimizing the potential for adverse effects. By detecting biomarkers that correlate with drug efficacy, toxicity, and/or tolerance, a doctor is able to choose the best drug (or best dose) for any given patient.

There is a growing trend in the pharmaceutical industry to codevelop new drugs with a related companion diagnostic. Patent protection is being pursued for these advancements. Is it right to incentivize personalized medicine with patents? Or are natural phenomena being discovered that are not properly the subject of patents? In Mayo, the companion diagnostic method at issue succumbed to precedent prohibiting patents from monopolizing laws of nature.

The question that remains is how much of a blow was dealt to future developments in disease diagnostics and personalized medicine by the Myriad and Mayo decisions? Are there other unintended consequences? More on that after the recap of the cases below.

\section{MYRIAD: "ISOLATING" DNA DOES NOT MAKE IT PATENTABLE (UNLESS IT IS EXONS-ONLY CDNA)}

Ask virtually anyone who is not (1) a discoverer of an important DNA molecule or (2) a patent lawyer who has been claiming such DNA molecules for years whether a human gene is something that should be the subject of a U.S. patent, and the answer, after a moment of confused silence, ranges from "I wouldn't think so" to "No, of course not." Whether as a matter of common sense or something more visceral, when the question is put this way, "Are human genes patentable?" a typical reaction is, "That cannot be possible. Man did not invent human genes. No one should be able to own, or monopolize, 'my' genes."

The issue before the Supreme Court in Myriad was phrased precisely that way by the American Civil Liberties Union (ACLU), representing a gathering of medical associations, genetic researchers, and patients who wanted to conduct or have (less costly) access to genetic testing for breast and ovarian cancers. ${ }^{12}$ The patents at issue in Myriad, claiming the so-called BRCA1 and $B R C A 2$ genes (and mutants thereof), gave Myriad Genetics, Inc. the right to exclude others from using the BRCA1 and BRCA2 genes

\footnotetext{
${ }^{12}$ See Petition for Writ of Certiorari at 3-6, Myriad (133 S. Ct. 2107) (2013) (No. 12-398).
} 
for cancer diagnostics. This did not sit well with the ACLU and its various plaintiffs. They mounted a lawsuit to challenge some, but not all, of Myriad's patent claims on the grounds that products of nature were impermissibly being claimed. The Supreme Court agreed. ${ }^{13}$

One of the challenged patents was U.S. Patent No. 5,747,282 (the '282 patent), which pertains to the BRCA1 gene. The patent emphasizes the seriousness of breast and ovarian cancer and the need for a diagnostic marker, a problem that the inventors solved. As the patent states:

Breast cancer is one of the most significant diseases that affects women. At the current rate, American women have a 1 in 8 risk of developing breast cancer by age $95 . .$. Treatment of breast cancer at later stages is often futile and disfiguring, making early detection a high priority in medical management of the disease. Ovarian cancer, although less frequent than breast cancer[,] is often rapidly fatal and is the fourth most common cause of cancer mortality in American women.... Mutation of one gene, BRCA1, is thought to account for approximately $45 \%$ of familial breast cancer, but at least $80 \%$ of families with both breast and ovarian cancer...[.]

Intense efforts to isolate the BRCA1 gene have proceeded since it was first mapped in 1990. ${ }^{14}$

Identification of a breast cancer susceptibility locus would permit the early detection of susceptible individuals and greatly increase our ability to understand the initial steps which lead to cancer.... [C]loning these genes could also be important in the development of better diagnostic and prognostic products, as well as better cancer therapies. $^{15}$

With this as background, the patent states that the invention relates to methods and materials used to isolate and detect a human cancer-predisposing gene (BRCA1) and to specific mutations of the gene and their use in diagnosing predisposition to breast and ovarian cancers.

\footnotetext{
${ }^{13}$ It is not yet clear what the ultimate effect of the Myriad decision will be. The $B R C A 1$ and $B R C A 2$ patent portfolio is large, and many of the patents are still being asserted by Myriad in several pending patent infringement suits.

${ }^{14}$ U.S. Patent No. 5,747,282, col. 2, 11. 44-63 (filed June 7, 1995) (citations omitted).

${ }^{15}$ Id. at col. 4, 1l. 23-28.
}

Exemplary claims of the '282 patent considered by the Supreme Court were (1) an isolated DNA coding for a BRCA1 polypeptide, said polypeptide having the amino acid sequence set forth in SEQ ID NO. $2^{16}$; and (2) the isolated DNA of claim 1, wherein said DNA has the nucleotide sequence set forth in SEQ ID NO. 1. ${ }^{17}$ Between the convention of claiming DNA in isolated form, the emphasis in the patent that efforts were intense to isolate the BRCA1 gene, and the representation by the inventors that they had isolated it, it is no wonder that the inquiry for patent eligibility by the courts, including the Supreme Court, focused on the act of "isolating" DNA. The problem with this approach, however, is that compositions of matter were being claimed, and not a process for isolating them.

The court expressed its holding twice in Myriad, and both times dismissed the notion that the isolated state of the claimed DNA placed it beyond the product-of-nature exception to patent eligibility: "We hold that a naturally occurring DNA segment is a product of nature and not patent eligible merely because it has been isolated.... We merely hold that genes and the information they encode are not patent eligible under $\$ 101$ simply because they have been isolated from the surrounding genetic material. ${ }^{18}$

Although the court acknowledged that the inventors had made a "medical breakthrough,"19 it noted that the claimed DNA molecules comprised the same nucleotide sequences and information content as the DNA in nature (i.e., the chromosomal DNA within a human cell). ${ }^{20}$ Therefore, "Myriad did not create anything." 21 The only word in the claim that differentiated the claimed DNA from the DNA in nature was "isolated." But, to the court's thinking, "separating [the] gene from its surrounding genetic ma-

\footnotetext{
16“SEQ ID NO. 2" is shorthand for the amino acid sequence of the protein encoded by the BRCA1 gene.

17 "SEQ ID NO. 1" is shorthand for the nucleotide sequence of cDNA encoding the BRCA1 protein.

${ }^{18}$ Myriad (133 S. Ct. at 2120) (emphases added).

${ }^{19}$ Id. at 2112 .

${ }^{20}$ Id. at 2116 .

${ }^{21}$ Id. at 2117 .
} 
terial is not an act of invention." ${ }^{22}$ When the patents at issue were filed, methods for isolating DNA were "well known." 23

Although the court understood that isolation technically creates new molecules with unique chemical compositions, it did not find the claims to be "expressed in terms of chemical composition" ${ }^{24}$ or to rely "on the chemical changes that result from isolation," 25 but, rather, were "concerned primarily with the information contained in the genetic sequence." ${ }^{.6}$ Because the information content was no different than that of the natural BRCAl gene, the claimed DNAs were not "markedly different" from what exists in nature, and the noninventive act of isolating could not save the claimed DNA from patent ineligibility.

It is unfortunate that the word "isolated" in claim 1 diverted the court along a path where a new and useful composition of matter was judged on the inventive merits of processes for DNA isolation, which, of course, were well established by the filing dates of the Myriad patents. Perhaps a greater focus on the product and not the process would have led to a different result. "Composition of matter" is a category of $\$ 101$ into which DNA unquestionably falls. Section 101 also requires that what is claimed be "new and useful." The convention of using the word "isolated" is meant to signify novelty over nature. The court acknowledged that, technically, the claimed DNAs were new molecules compared to the native BRCA1 nucleotide stretch in the chromosome. "Isolated," therefore, could simply have been viewed to satisfy the newness requirement of $\$ 101$, as it had been for many years by the USPTO. And there is no question that the BRCA genes are useful. Their discovery has provided a diagnostic test that allows

\footnotetext{
${ }^{22} I d$.

${ }^{23} I d$. at 2112.

${ }^{24} I$ d. at 2110 .

${ }^{25} \mathrm{Id}$. at 2118 .

${ }^{26} I d$. at 2118. Actually, these claims are drafted in a conventional format for claiming DNA as a chemical compound and would be understood by those in the art to claim molecules chemically distinct from what exists in nature. The nucleotide sequence, in addition to conveying information, provides the chemical structure of the claimed DNA.
}

women to make decisions that save their lives. The undiscovered chromosomal DNA did not have that utility. Viewed in terms of utility (as in the Parke-Davis, Merck, and Merz cases, supra), it is not difficult to conclude that discovered DNAs are "markedly different" than their undiscovered counterparts in nature. In that sense, they meet the Chakrabarty test for patent eligibility.

Claim 2, directed to cDNA, was considered patent-eligible, even though its information content is no different than what exists in nature. A cDNA molecule is made by man and has a structure unlike what exists in nature, assuming the cDNA corresponds to a stretch of genomic DNA containing introns, complements of which would not exist in the cDNA. If the cDNA is a short segment corresponding entirely to all or part of an exon, it "may be indistinguishable from natural DNA" and, therefore, not eligible for patenting. ${ }^{27}$

Myriad ends with the court noting what is not implicated by the decision. No method claims were before the court. New applications of knowledge of the BRCA genes were not the subject of claims before the court. In line with its precedent (e.g., Diamond v. Diehr (450 U.S. 175) (1981)), the court hints that a new application of knowledge of $B R C A 1$ and $B R C A 2$ genes may be patentable. But as we shall see in the next section, the Mayo decision, which preceded Myriad by about a year, made claiming applications for biomarkers like the BRCA genes as challenging as Myriad made claiming the biomarkers themselves.

\section{Mayo: Patenting Applications of Laws of Nature-A Cautionary Tale for Companion Diagnostics and Personalized Medicine}

The patented methods at issue in Mayo allow doctors to determine the optimal doses of certain drugs used to treat people with autoimmune disorders, such as Crohn's disease. When thiopurine drugs enter the human bloodstream, they are converted into metabolites that

\footnotetext{
${ }^{27} I d$. at 2119 .
} 
function to treat the disorder. It was known that different patients metabolized these drugs differently. That is, the same dose given to two different patients could result in different levels of the metabolite in their blood. Too low a level of metabolite might be ineffective, and too high a level might be toxic. Either situation would require adjustment of the dose of the drug. Of course, a dose of the drug resulting in a safe and efficacious amount of the metabolite would not require adjustment.

Although doctors appreciated that a patient taking a thiopurine might need to have the dose of the drug adjusted, the patented methods provided them with a more precise gauge for making those adjustments. The inventors had identified concentrations of the metabolite that, if detected in the patient's blood, would suggest either an increase, decrease, or no change in the administered dose of the drug.

The claims of the patents at issue in Mayo were phrased as follows:

A method of optimizing therapeutic efficacy for treatment of an immune-mediated gastrointestinal disorder, comprising:

(a) administering a drug providing [the metabolite] to a subject having [the disorder]; and

(b) determining the level of [the metabolite] in [the] subject. .., wherein the level of [the metabolite] less than [a first specific concentration] indicates a need to increase the amount of drug subsequently administered to [the] subject and wherein the level of [the metabolite] greater than [a second specific concentration] indicates a need to decrease the amount subsequently administered to [the] subject.

The claimed method is one type of companion diagnostic, a means for monitoring and/or adjusting the dose of a specific drug for a particular patient. The court recognized that this method involved a correlation-that is, the concentration of metabolite signifying a need to maintain, increase, or decrease the dose of the drug. The court viewed this as a natural correlation and proceeded with its analysis of whether the claim covered a patent-eligible application of the correlation or was tantamount to claiming a natural phenomenon, which is not permissible. It concluded the latter. ${ }^{28}$

Supreme Court precedent dictated that processes that too broadly preempt the use of a natural law are not eligible for patenting. Precedent also dictated that a patent claim reflect an "inventive concept" independent of the newly discovered law of nature to "ensure that the patent in practice amounts to significantly more than a patent upon the natural law itself." 29 The patent claim in Mayo did not meet these conditions. The steps of administering the drug, determining the level of the metabolite, and taking that level into consideration for dose adjustment were viewed as "well understood, routine [and] conventional activity." ${ }^{30}$ In effect, the claim language was at such a high level of generality that it did no more than present the correlation and say "apply it," and this was insufficient to place the method into the realm of a patent eligible application of a natural law. ${ }^{31}$

Repeatedly throughout the decision, the court expressed concerns that too much patenting may actually impede innovation. Recognizing that awarding patents on methods involving laws of nature may encourage future discoveries of useful natural correlations, the court nevertheless had greater concerns about granting patent monopolies on laws and principles that are the basic tools of research: "And so there is a danger that the grant of patents that tie up [the use of natural laws] will inhibit future innovation premised upon them...."32

Mayo has made uncertain how best to draft a patent claim to a method involving a natural correlation. It does not deal a fatal blow to patenting methods in the area of personalized med-

\footnotetext{
${ }^{28}$ The correlation involved here was not the least bit "natural." The metabolite that serves as the marker is not naturally occurring in a human. A man-made drug, which also does not exist in nature, had to be administered to a patient to result in the non-naturally occurring metabolite. The court rationalized its view that a natural correlation was at issue because the metabolism of the drug by a human involves natural processes.

${ }^{29}$ Mayo (132 S. Ct. at 1294).

${ }^{30} \mathrm{Id}$.

${ }^{31} I d$.

${ }^{32} I d$. at 1301.
} 
J. Gordon

icine and companion diagnostics; it just makes thing more complicated. The court called for claims that "do significantly more" than simply describe the natural correlation. "Enough" has to be added to the claim to ensure an application of the natural law is being claimed: "If a law of nature is not patentable, then neither is a process reciting a law of nature, unless that process has additional features that provide practical assurance that the process is more than a drafting effort designed to monopolize the law of nature itself." 33

We know that the language of the claims at issue in Mayo was considered to be too general. Unfortunately, little guidance was provided as to what level of specificity in patent claims of this nature would allay the Court's concerns. The cycle of testing appropriate claim language for biological inventions in the USPTO and the courts begins anew.

\section{THE AFTERMATH}

Certain effects of Myriad and Mayo were immediate. On March 20, 2013, the day the court decided Mayo, thousands of claims to diagnostic methods in U.S. patents became invalid under 35 U.S.C. \$101. Similarly, on June 13, 2013, the day the court decided Myriad, thousands more patent claims to isolated DNA became invalid. This can be said with some certainty because the wording of the claims in Mayo and Myriad was standard practice in biotech patents. Indeed, until Myriad, the USPTO endorsed the "isolated" DNA format for claims.

On the same day that Myriad was decided, the USPTO issued guidance in line with the Supreme Court's holding. ${ }^{34}$ Claims to isolated DNA would no longer be patent-eligible under 35 U.S.C. $\$ 101$, but claims limited to non-naturally occurring nucleic acids, such as cDNA or synthetic DNAs with man-made variant sequences, would remain eligible. ${ }^{35}$ On March 4, 2014, the USPTO issued more comprehensive

\footnotetext{
${ }^{33}$ Id. at 1297 .

${ }^{34}$ See Memorandum from Andrew Hirshfield, Deputy Commissioner for Patent Examination Policy, June 13, 2013.

${ }^{35} \mathrm{Id}$.
}

guidance $^{36}$ on patent subject matter eligibility determinations. The guidance extends the holding of Myriad beyond nucleic acids to all natural products (including, e.g., proteins and antibiotics). At a public forum on May 9, 2014, the guidance was harshly criticized by patent attorneys practicing in the life sciences area.

Those who prosecute biotech patent applications are reporting that examiners are using 35 U.S.C. $\$ 101$ as grounds for rejection with greater frequency. The $\$ 101$ rejections are being leveled at diagnostic method claims as applicants test where examiners will draw the line between finding the claim language so general that a natural correlation is, in effect, being claimed and finding that the claim presents an inventive concept independent of the newly discovered natural correlation.

Although $\$ 101$ rejections are being overcome by applicants, obtaining patents on diagnostic methods comes at a price. That price is a narrower claim scope. For example, prior to Mayo, the broadest claim in a patent on a biomarker-based diagnostic method did not specify the detection method. Since Mayo rejected such a claim format, the USPTO has issued guidance suggesting that the claim should recite that the biomarker is detected in a particular way (e.g., flow cytometry) with a particular reagent (e.g., a specific antibody). ${ }^{37}$

The bottom line is that after Mayo, the USPTO will grant narrowly drafted claims of significantly less commercial value. Narrow claims make it easier for copyists to design around the specific details. They get the benefit of a newly discovered natural correlation without infringement risk and without the research effort and dollars expended by the patentee. The Mayo court viewed this result as promoting progress, but does it? At some point, the narrowness of available claim scope from the USPTO will deter the patenting of these kinds of inventions, if not the vitally important research that underlies them. To be sure, patent applicants will con-

\footnotetext{
${ }^{36}$ See Memorandum from Andrew Hirshfield, Deputy Commissioner for Patent Examination Policy, March 4, 2014. ${ }^{37} I d$.
} 
tinue to fight for commercially significant claim scope, but we are in uncharted waters for the foreseeable future. Even if patents issue, they may still be tested in the courts. From Myriad and Mayo, we know what broad claim language to avoid, but we do not yet know how close we can get to it.

While things unfold in the USPTO, the effects of Myriad and Mayo are playing out in the courts. The recent decision of Ariosa Diagnostics, Inc. v. Sequenom, Inc., illustrates how deadly to diagnostic patents the combined effects of Myriad and Mayo can be. ${ }^{38}$ In this case, the inventors of the patent-in-suit had discovered that cellfree fetal DNA (cff DNA) could be detected in maternal serum and plasma samples. This discovery provided the basis of a noninvasive way to do prenatal diagnostics and to diagnose the serious condition of preeclampsia in the mother. Conventional prenatal diagnostic DNA tests, such as amniocentesis and chorionic villus sampling, which involve invasive procedures, could now be avoided. An exemplary patent claim was phrased, "a method for performing a pre-natal diagnosis on a maternal blood sample, which method comprises obtaining [a maternal serum or plasma] sample, amplifying [cff DNA] and performing nucleic acid analysis on the amplified nucleic acid to detect [cff DNA]."

This claim was invalidated by the district court under 35 U.S.C. $\$ 101$, following the reasoning of Mayo. It mattered not that the cff DNA was newly discovered or that it could be used in a noninvasive procedure to provide diagnostically important information about the health of the fetus and the mother. The claim was drafted too broadly, and methods for amplifying DNA were conventional. The claim was found to essentially cover the natural phenomenon itself and was invalidated per Mayo. And, of course, Myriad would make the newly discovered cff DNA patent-ineligible as well. Is this progress or a veritable bonanza for erstwhile infringers?

This scenario will undoubtedly play out in other cases on patents with similar claims. Such is the immediately foreseeable consequence of

${ }^{38} 2013$ WL 5863022 (N.D. Cal. 2013).
Myriad and Mayo. But there are other potential consequences. The thinking in Myriad that isolated DNA is a patent-ineligible product of nature may well be extended to other purified natural substances. ${ }^{39}$ There are many useful substances in the natural world waiting to be discovered. As just one example, with bacteria becoming resistant to standard antibiotics, do we want to disincentivize the discovery of new natural antibiotics by making patent protection for them impossible? As another example, testing positive for BRCA1 or BRCA2 mutations causes women (such as, most famously, the actress Angelina Jolie) to have prophylactic double mastectomies. However, there may be some small subset of women who, although they test positive for BRCA1 or BRCA2 mutations, will not develop breast or ovarian cancer. Do we not wish to incentivize the research that might lead to the discovery of new genetic biomarkers with which to identify women who need not undergo disfiguring and life-altering surgeries?

It is too early to tell whether the ramifications of Myriad and Mayo will be dire or not, but if the Ariosa case is any indication, they could be. Perhaps the so-last-century, strict ban on patenting laws of nature and natural phenomena needs to be loosened. A legislative fix may well be in order. As if to suggest that that might be the case, the court in Mayo noted: "[W] e must recognize the role of Congress in crafting more finely tailored rules where necessary." ${ }^{\prime 0}$ Are such rules now necessary? Let the debate begin.

\section{ACKNOWLEDGMENTS}

The views expressed herein are solely those of the author, who has spent more than 30 years practicing biotechnology patent law. The author wishes to acknowledge Sean McDonagh of Baker Botts LLP for his assistance with this review.

\footnotetext{
${ }^{39}$ As noted above, the USPTO has extended the holding of Myriad to all natural products in its guidance on patent eligibility determinations. The courts have recently found "Dolly the Sheep," a cloned mammal, ineligible for patenting as not markedly different from the original donor sheep. In re Roslin Institute (Edinburgh), Slip. Op. 2013-1407 (Fed. Cir., May 8, 2014).

${ }^{40}$ Mayo (132 S. Ct. at 1305).
} 


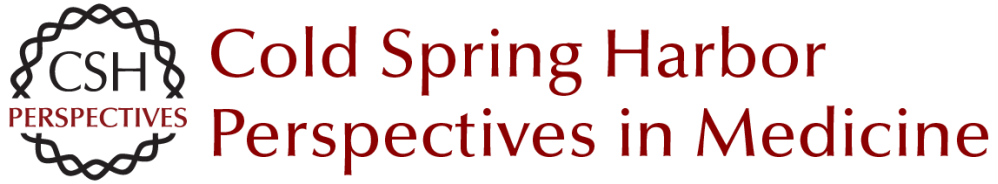

\section{The Impact of Myriad and Mayo: Will Advancements in the Biological Sciences Be Spurred or Disincentivized? (Or Was Biotech Patenting Not Complicated Enough?)}

Jennifer Gordon

Cold Spring Harb Perspect Med 2015; doi: 10.1101/cshperspect.a020917 originally published online December 11, 2014

Subject Collection Intellectual Property in Molecular Medicine

Patentability of Stem Cells in the United States Sarah E. Fendrick and Donald L. Zuhn, Jr.

Inventorship and Authorship Antoinette F. Konski and Linda X. Wu

The Patentability of Stem Cells in Australia Jenny Petering and Prue Cowin

Impact of America Invents Act on Biotech Intellectual Property

Amanda Murphy, Michael Stramiello, Jonathan Stroud, et al.

Introduction to Intellectual Property: A U.S.

Perspective

Amanda Murphy, Michael Stramiello, Stacy Lewis, et al.

The Role of Regulatory Agencies and Intellectual Property: Part I

Kevin E. Noonan

Canada's Patented Medicines (Notice of Compliance) Proceedings and Intellectual Property Henry Bian and Conor McCourt

Patentability of Genes: A European Union

Perspective

Paul Cole
The Impact of Myriad on the Future Development and Commercialization of DNA-Based Therapies and Diagnostics

Michele Wales and Eddie Cartier

Protecting Traditional Knowledge Related to

Biological Resources: Is Scientific Research

Going to Become More Bureaucratized?

Prashant Reddy and Malathi Lakshmikumaran

Protecting Trade Secrets in Canada

Noel Courage and Janice Calzavara

Inherent Anticipation in the Pharmaceutical and

Biotechnology Industries

Michael Goldman, Georgia Evans and Andrew Zappia

The Role of Regulatory Agencies and Intellectual

Property: Part II

Kevin E. Noonan

Baseball Bats and Chocolate Chip Cookies: The Judicial Treatment of DNA in the Myriad Genetics Litigation lan Binnie and Vanessa Park-Thompson

The Impact of Myriad and Mayo: Will

Advancements in the Biological Sciences Be

Spurred or Disincentivized? (Or Was Biotech

Patenting Not Complicated Enough?) Jennifer Gordon

Trade Secrets in Life Science and Pharmaceutical Companies

Tara Nealey, Ronald M. Daignault and Yu Cai

For additional articles in this collection, see http://perspectivesinmedicine.cshlp.org/cgi/collection/ 